Pesq. Vet. Bras. 30(6):510-514, junho 2010

\title{
Intersexuality in a crab-eating fox (Cerdocyon thous) ${ }^{1}$
}

\author{
Marcos R.F. Mattos ${ }^{2}$, Lucilene Simões-Mattos², Célso Pilati ${ }^{3}$, Lúcia D.M. \\ Silva $^{4}$ and Sheyla F.S. Domingues ${ }^{5}$
}

\begin{abstract}
Mattos M.R.F., Simões-Mattos L., Pilati C., Silva L.D.M. \& Domingues S.F.S. 2010. Intersexuality in a crab-eating fox (Cerdocyon thous). Pesquisa Veterinária Brasileira 30(6):510-514. Unidade Acadêmica de Garanhuns, Universidade Federal Rural de Pernambuco, Av. Bom Pastor s/n, Boa Vista, Garanhuns, PE 55292-270, Brazil. E-mail: mattos@uag.ufrpe.br

Intersexuality is a reproductive pathology that has been described in wild animals in recent years. However, its occurrence and consequences remain obscure and therefore all aspects of this reproductive disorder deserve attention. The aim of this study is to report a case of intersexuality with probable absence of gonadal tissue in the crab-eating fox (Cerdocyon thous) native to Brazil. The animal has male external genitalia, but its prepuce and penis were both hypoplastic. Because of a clinical suspicion of bilateral cryptorchidism, a laparotomy was performed and the absence of prostate and gonads were revealed. The procedure also revealed vas deferentia, extending laterally from the each side of the bladder basis to the right and left abdominal wall muscles. The animal died one month later, and post mortem examination confirmed the absence of prostatic and gonadal tissues. Muscular structures similar to uterine horns and cervix were founded macroscopically and confirmed by optic microscopy. In addition, post mortem findings corroborate with penis hypoplasia, since penile bone presence was observed. The vasa deferentia had a normal tissue structure, although hypoplastic. In conclusion, the case of a crab-eating fox (Cerdocyon thous) reported here represents a proved intersexual animal with probable absence of gonadal tissue.
\end{abstract}

INDEX TERMS: Cerdocyon thous, crab-eating fox, gonadal absence, intersexuality, reproductive pathology.

RESUMO.- [Intersexualidade em uma raposa (Cerdocyon thous).] A intersexualidade é uma das patologias reprodutivas, hereditária e/ou congênita, que têm sido mais reportada em animais selvagens nos últimos anos. Entretanto, suas ocorrências e conseqüências permanecem

\footnotetext{
${ }^{1}$ Received on April 14, 2010.

Accepted for publication on June 10, 2010.

2 Unidade Acadêmica de Garanhuns (UAG), Universidade Federal Rural de Pernambuco (UFRPE), Av. Bom Pastor $s / n$, Boa Vista, Garanhuns, PE 55292-270, Brazil. ${ }^{*}$ Corresponding author: mattos@uag.ufrpe.br

${ }^{3}$ Centro de Ciências Agroveterinárias (CAV), Universidade do Estado de Santa Catarina (UDESC), Av. Luiz de Camões 2090, Conta Dinheiro, Lages, SC 88520-000, Brazil.

${ }^{4}$ Faculdade de Veterinária (FAVET), Programa de Pós-Graduação em Ciências Veterinárias (PPGCV), Universidade Estadual do Ceará (UECE), Av. Paranjana 1700, Itaperi, Fortaleza, CE 60740-000, Brazil.

${ }^{5}$ Laboratório de Biologia e Medicina de Animais da Amazônia, Faculdade de Medicina Veterinária, Universidade Federal Pará, Rua Hernane Lameira 556, Castanhal, PA 68743-050, Brazil.
}

obscuras, sendo que todos os aspectos relacionados a este distúrbio reprodutivo merecem atenção. O objetivo deste estudo foi relatar um caso de intersexualidade com provável ausência de tecido gonadal em uma raposa $(\mathrm{Cer}$ docyon thous) do Brasil. O animal apresentava sexo fenotípico masculino, mas seu prepúcio e pênis eram pequenos. Devido a uma suspeita clínica de criptorquidismo bilateral, foi realizada uma laparotomia, sendo, no procedimento cirúrgico, revelada a ausência de próstata e gônadas. Os ductos deferentes foram localizados lateralmente à bexiga, entendendo-se desde a sua base, inserindo-se na musculatura da parede abdominal direita e esquerda. Um mês após, o animal morreu e os achados necroscópicos confirmaram a ausência de tecidos prostático e gonadal. Entretanto, uma estrutura muscular histologicamente semelhante a cornos e cérvix uterinos foram encontradas. Além disso, pelo mesmo método, ratificou-se a ausência de próstata e o pênis exibiu aspecto normal contendo osso peniano. Os ductos deferentes apresentaram estrutura 
tecidual normal, porém hipoplásicos. Concluiu-se que o caso reportado no presente trabalho representa um exemplo de intersexualidade com provável ausência de tecido gonadal em um animal da espécie Cerdocyon thous.

TERMOS DE INDEXAÇÃO: Cerdocyon thous, raposa, ausência gonadal, intersexualidade, patologia reprodutiva.

\section{INTRODUCTION}

The diagnosis of reproductive pathologies is important for the success of wild animal conservation programs, because may prevents the dissemination of undesirable reproductive characteristics. Errors in the establishment of chromosomal, gonadal, or phenotypic sex usually cause abnormal sexual differentiation, that can result in rare reproductive pathologies, among then intersexuality (Lyle 2007). Nonetheless, in recent years, the number of intersexuality case reports has been growing in wild animals (EPA 1997). Some researchers have hypothesized that this condition might be due to environmental contamination, mainly by endocrine-disrupting chemicals (EPA 1997, Wiig et al. 1998, Brunstrom \& Halldin 2000), or by effects of habitat loss and fragmentation on wild animal genetic variability and reproduction (Wildt et al. 1995, Jobling et al. 2002, Lukas \& Walter 2002). However, to associate abnormal sexual differentiation to the environmental factors still difficult and must remain, in many cases, as suggestive etiology. Even though that environmental etiology is tenuous, intersexuality reports in wild animals are important for further studies to complete knowledge of the possible environmental pathogenesis causes. Thus, the aim of this paper is to report a case of intersexuality with the probable absence of gonads in a crab-eating fox (Cerdocyon thous) from Brazil.

\section{MATERIALS AND METHODS}

In May 1998, the Instituto Brasileiro do Meio Ambiente e Recursos Naturais Renováveis (IBAMA) recovered an approximately two-year-old crab-eating fox (Cerdocyon thous) from the house of a person who had kept it as a pet since it was a cub, having illegally purchased it from a wild animal trader. The animal was recovered and transferred by IBAMA to the municipal public zoo (Zoológico Municipal Sargento Prata, Fortaleza, Ceará, Brazil).

In 1999, as part of a reproductive program, the fox was submitted to clinical and behavioral evaluation. The animal showed no libido and sometimes aggressiveness towards female in estrus. At a physical examination, the animal was apparently healthy, weighing $7 \mathrm{~kg}$; however an extensive adipose tissue deposition on the abdominal subcutaneous region was noted. In addition, the animal had hypostatic prepuce, penis and scrotum (Fig.1). The pelvic and abdominal palpation indicated that there were no testicles inside the scrotal sac, inguinal channel or in abdominal subcutaneous tissue. A careful abdominal and pelvic 2D B mode ultrasound examination revealed probable gonad structure absence.

Due to a clinical suspicion of bilateral cryptorchidism, the animal was submitted to the laparotomy procedure in September 1999. The prostatic and gonadal absences were detected during this surgery. The inguinal channel, abdominal

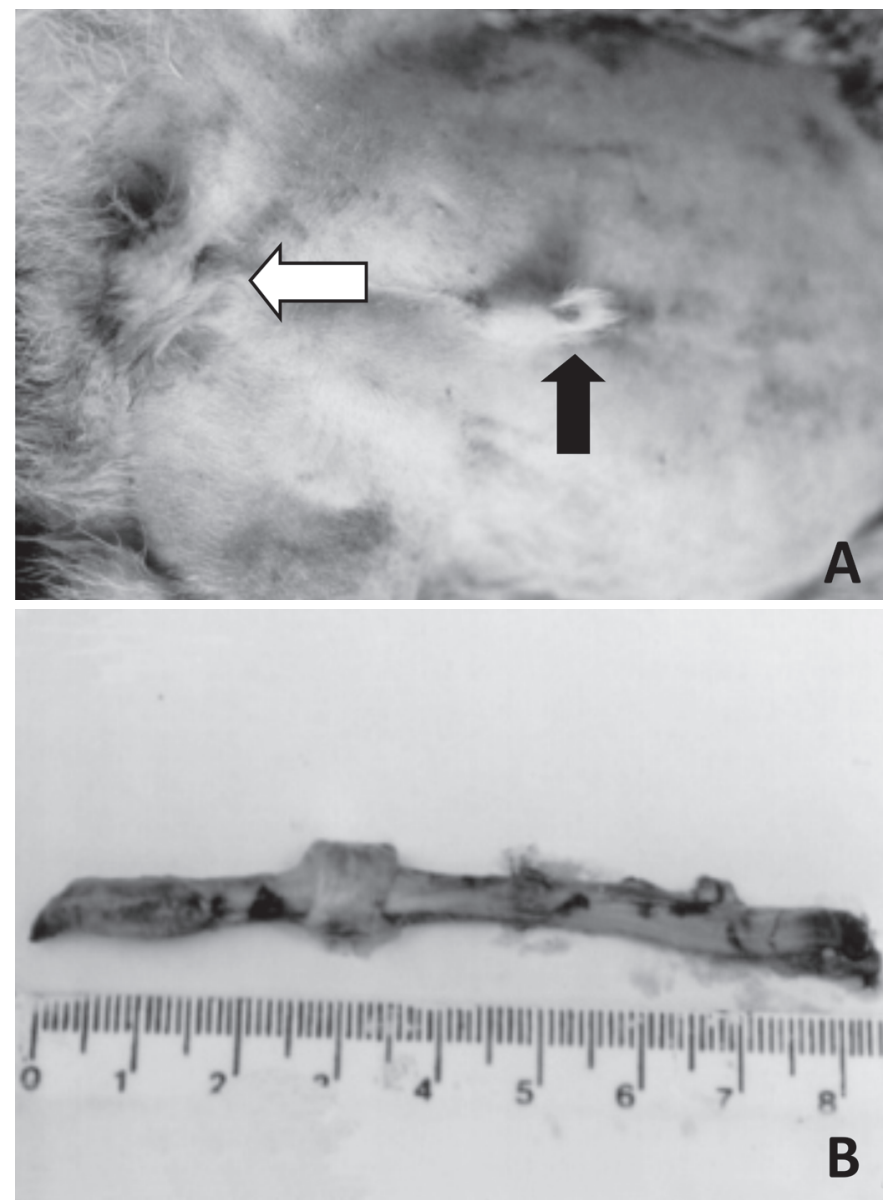

Fig.1. External sex organs of the crab-eating fox (Cerdocyon thous). (A) Ventral view of the abdomen showing a smallsized prepuce (black arrow) and scrotum (white arrow). (B) Dissected penis.

cavity, caudal portions of both kidneys and base of the bladder were carefully investigated for the presence of the male reproductive structures. The caudal section of the vasa deferentia had the normal localization, near the base of the bladder. Interestingly, it was bilaterally inserted into the right and left abdominal wall muscles, approximately two inches from the inguinal canal. Thus, since no gonadal structures were found, complementary endocrine and genetic assays were scheduled for after the postoperative period. However, the animal died of canine distemper one month later and these complementary assays were not able to be performed.

\section{RESULTS}

On the post mortem examination, because of clinical suspicion of bilateral cryptorchidism, all the possibilities of testicular ectopy were investigated. The abdominal cavity, abdominal and pelvic subcutaneous tissues, inguinal channel, perineum and adjacent regions, the medial part of the pelvic limbs, and regions around or inside the prepuce were the main targets. Only an elongated muscular structure (Fig.2A and 3 ) was found in the abdominal cavity, between the kidneys and the bladder. This structure was located ventrally, near and along the lumbar spine, and was fully 

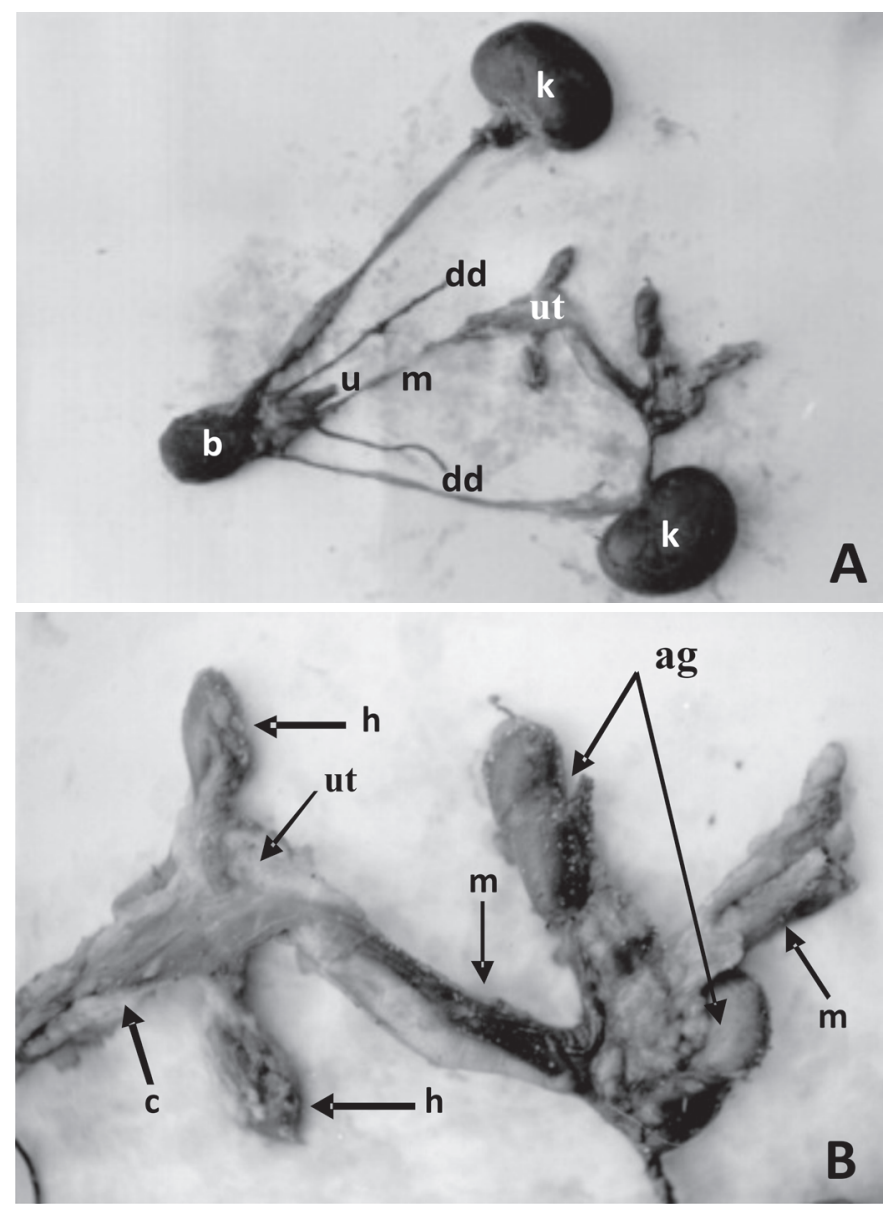

Fig.2. Excised internal urogenital tract of the crab-eating fox (Cerdocyon thous). (A) kidneys (k), bladder (b), urethra (u), ductus deferens (dd), thin muscle tissue $(\mathrm{m})$, uterus-like muscle tissue (ut). (B) Detail of Figure 2A. Uterus-like muscle tissue (ut), cervix-like muscle tissue (c), uterus-like muscle tissue with a "cul-de-sac" shape (h), muscle tissue (m), bilobulated adrenal (ag).

surrounded by dense adipose tissue, which had hindered its visualization during the surgical procedure. The caudal portion of this structure was thin and linked to the urinary bladder base. In its intermediate region, there was a large saclike muscular structure linked on each side by two small cul-de-sac pouches (Fig.2B). Due to its anatomic position and aspect, the elongated structure resembled a rudimentary female tubular reproductive tract (vagina, cervix, uterine body and horns). Cranially, the structure was prolonged and linked to the adrenal glands, which had a bilobular shape. The adrenal shape may suggest that this organ is bilobulated in this particular animal species.

The thoracic and abdominal musculature, especially where the vasa deferentia were inserted, as well as the pelvic and abdominal organs and pelvic muscle tissue were also inspected, but no gonads were found. The post mortem macroscopic findings suggested a diagnosis of intersexuality. The entire urogenital tract, all the saclike structure, its cranial and caudal extensions and, the two small cul-de-sac pouches,

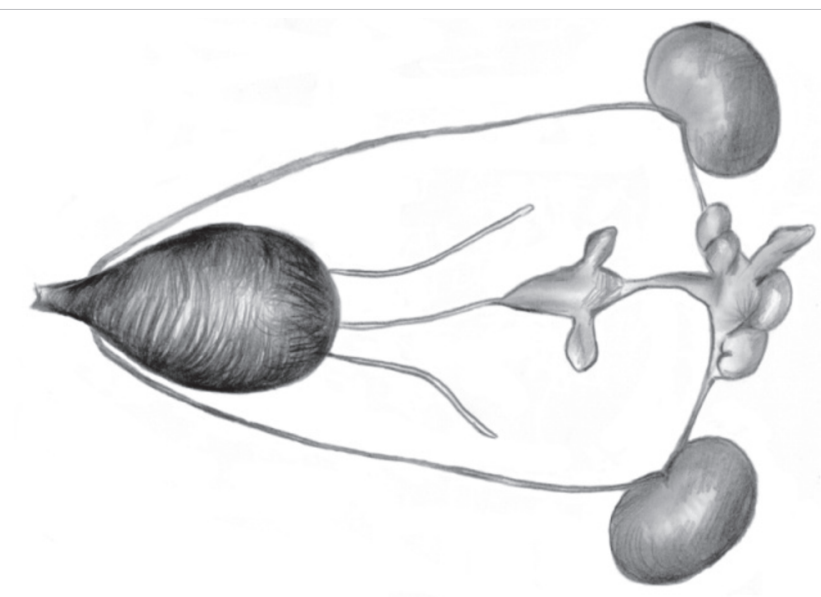

Fig.3. Model scheme of the urogenital tract showing its true shape in the abdominal cavity of the crab-eating fox (Cerdocyon thous).

the adrenal glands, vasa deferentia as well as fragments of abdominal muscles were fixed in $10 \%$ buffered formalin solution. Several fragments of all structures were processed for optic histology and stained with Hematoxylin-Eosin.

Optic microscopy analysis showed that all the saclike structure and the small cul-de-sac pouches had muscular and glandular tissues resembling the uterus (cervix, body and horns). The entire structure was surrounded by a serous membrane. Histology confirmed the bilobular aspect of the adrenal previously observed macroscopically. No prostatic tissue was found on the bladder base or near it. Furthermore the vasa deferentia had a normal tissue structure, but were hypoplastic. In addition, the muscles where the vasa deferentia had its insertion showed normal anatomic and histological patterns. The urinary bladder, the kidneys, the ureters and the urethra and penis (with a penile bone) had also the same normal pattern. In all evaluated organs, gonadal tissues were not found.

\section{DISCUSSION}

Data concerning reproductive developmental and sexual differentiation abnormalities, i.e. cryptorchidism and intersexuality, are important to prevent reproductive undesirable characteristics propagation in captivity programs or when a planned reintroduction is on scope. In this respect, any occurrence of abnormal sexual development in wild animals suggests the need for a more detailed evaluation or even the removal of relatives, mainly the progenitors, of these animals from reproductive programs. The crab-eating fox reported here is an example of such occurrence. The animal has phenotypic male genitalia with prepuce, penis, and scrotum, as well as internal structures that assembly uterus and cervix, thus able to classify it as intersexual. The kind of intersexuality is difficult to affirm, however, since no gonad was found and the genetic sex cannot be determined by karyotype. In this sense, the diagnosis of the several kinds of intersexuality, such as chimaerism, mosaicism, sex reversal syndrome, and male or female pseudo- 
hermaphroditism, must be based on the inspection of the chromosomes, tissue composition of gonad and the phenotypic appearance of the internal reproductive organs and external genitalia (Kuiper \& Distl 2004). Nonetheless, in this animal a careful evaluation of anatomic and histological aspects allowed us to state that this animal probably had no gonadal and prostatic structures. The prostate is only accessory gland in dogs, foxes and, probably in all canids, with a large anatomic structure easily localized on the urinary bladder base. Thus, if the prostate had been present, it probably would have been found which permits us to speculate that prostatic agenesis or prostatic abiotrophy has occurred. This abnormality is of the extremely rare occurrence and to our knowledge it has never been reported before in wild animals.

Briefly, the sex differentiation in mammals occurs in three steps (Val \& Swain 2005). The first is the establishment of chromosomal sex at fertilization, followed by the differentiation of the gonad into an ovary or testis, and finally the establishment of the fetal phenotypic sex, which is regulated by the gonad functionality. Disruption of any of these stages gives rise to sexual ambiguities, usually denominated as intersexuality, a non-specific term that does not denote the nature or etiology of the abnormality. Currently, factors such as environment contamination and/or low genetic variability are being inculpated as the etiologies of the low reproductive performance and abnormal sexual development of several wild animal species (Wildt et al. 1995, EPA 1997, Brunstrom \& Halldin 2000). Since the early 1990's, it has been established that a wide variety of natural or man-made chemicals in the environment are capable of modulate, adversely affect or even disrupt endocrine functions in vertebrate organisms (EPA 1997, Gross et al. 2002). Intersexuality, including cases of hermaphroditism and other reproductive disorders such as masculinization and feminilization related to environmental contamination has occurred in several wild animal species, including mammals (Reijnders 1986, Cattet 1988, Facemire et al. 1995, Brunstrom \& Halldin 2000, Yu et al. 2000). In the case of this crab-eating fox, the reproductive disorders may have been due to chemical contamination. The total lack of prior research, however, makes us cautious about being definite about this etiology. In addition, it is very difficult to attribute the action of pollutants as a direct cause of intersexuality, in this case, because, as mentioned earlier, the animal must have been exposed to the chlorinated pesticides or other contaminants in the uterus or in the perinatal period during the development of genital organs. Thus, the presence of pollutant residues in the body tissues of adult animals may be irrelevant, hindering an efficacious measurement. If they were present, they should not be designated a priori as etiologic agents, since it is not known whether they caused early contamination in utero or not.

It is known that anthropic influences such as urban and agricultural expansions are the principal causes of fragmentation and reduction of natural habitats, which consequently can lead to genetic variability loss by consanguinity in wild animal species due to geographical isolation of small groups. Thus, an increase in genetic disorders may be observed (Facemire et al. 1995). In Northeastern Brazil, including the Caatinga Biome, where the fox was captured, there is a high degree of fragmented areas. Thus, the consanguinity may also be possible in this case.

These reproductive pathologies such as ovarian agenesis, monorchidism, anorchidism and polyorchism are rarely diagnosed in human beings (Serban et al. 1965, Abate et al. 1968, Tomov \& Ankov 1987, Lamesch 1992, Mulayim, Gorgojo et al. 2002, Demirbasoglu \& Oral 2003 ). These pathologies are considered to be extremely rare in domestic animals (Mattos et al. 2001), with few cases reported in carnivores (Bloom 1954, Reis 1966, Lyle 2007). However, the cryptorchidism has been reported in wild mammals, and it is probable a strong association with environmental contamination or consanguinity (Burton \& Ramsay 1986, Dumbar et al. 1996, Michalski et al. 2001, Buergelt et al. 2002, Mansfield \& Land 2002, Latch et al. 2008). However, to our knowledge, the total absence of gonads in a wild mammal has not been reported, yet. Based on the anatomic and microscopic findings, we suggest that this is probably a case of gonadal agenesis in a crab-eating fox. Nonetheless, to prove the absence of gonadal tissue, some hormonal assays would be useful. For the diagnosis of anorchidism, human chorionic gonadotrophin or gonadotrophin releasing hormone $(\mathrm{GnRH})$ assays are used (Pierson et al. 1983, Tzvetkova et al. 1997). Similarly, follicle stimulating hormone, human menopausal gonadotrophin and GnRH assays may also be used to confirm the absence of ovarian tissue (Singh \& Madan 1997, Mendez et al. 1998). Unfortunately, in the present case, the animal died, due a canine distemper, before a hormonal response assay could be performed. Despite this, according to Pierson et al. (1983), an accurate surgical investigation is enough for the diagnosis of anorchidism or monorchidism in human beings, and this was the procedure followed in the present case, including a careful necropsy.

In conclusion, the case of a crab-eating fox (Cerdocyon thous) reported here represents a proved intersexual animal with probable absence of gonadal tissue. These findings are extremely rare in domestic and wild mammalian species. In addition, this case may be useful to signal potential environmental disruptions that may hindered the wildlife conservation program. Then, this case serves as a sign for wild animal conservation that similar cases possibly are not being diagnosed or are being neglected.

Acknowledgments.- We devote this paper to Dr. Thomas J. Burke (in memoriam), University of Illinois, USA, for his encouragement and generous cooperation. We wish to thank Dr. Nick Lunn (Canadian Wildlife Service) and Dr. Luis Viana Diniz (Zoológico Municipal Sargento Prata, Fortaleza, Brazil) for technical support.

\section{REFERENCES}

Abate G., Ferramosca B., Piazzi G. \& Bonavita E. 1968. Congenital anorchidism with partial anterior hypopituitarism. Folia Endocrinol. 21:485-500.

Bloom F. 1954. Congenital anomalies, the genitourinary system, with 
clinical considerations, p.384-385. In: Bloom F. (Ed.), Pathology of the Dog and Cat. Evanston, Illinois.

Brunstrom B. \& Halldin K. 2000. Ecotoxicological risk assessment of environmental pollutants in the Arctic. Toxicol. Lett. 112/113:111-118.

Buergelt C.D., Homer B.L. \& Spalding M.G. 2002. Causes of mortality in the Florida panther (Felis concolor coryi). Annals New York Acad. Sci. 969:350-353.

Burton M. \& Ramsay E. 1986. Cryptorchidism in manned wolves. J. Zoo An. Med., 17:133-135.

Cattet M. 1988. Abnormal sexual differentiation in black bears (Ursus americanus) and brown bears (Ursus arctos). J. Mammol. 69:849852.

Dunbar M.R., Cunningham M.W., Wooding J.B. \& Roth R.P. 1996. Cryptorchidism and delayed testicular descent in Florida black bears. J. Wildl. Dis. 32:661-664.

EPA 1997. Special report on environmental endocrine disruption: An effects assessment and analysis (EPA/630/R-96/012). Proc. Office of Research and Development, Risk Assessment Forum, U.S. Environmental Protection Agency, Washington, DC. 111p.

Facemire C.F., Gross T.S. \& Guillette Jr L.J. 1995. Reproductive impairment in the Florida panther: Nature or nurture? Environ. Health Perspect. 103(Suppl.4):79-86.

Gorgojo J.J., Almodovar F., Lopez E. \& Donnay S. 2002. Gonadal agenesis $46 \mathrm{XX}$ associated with the atypical form of Rokitansky syndrome. Fertil. Steril. 77:185-187.

Gross T.S., Sepulveda M.S., Arnold B.S., Wieser C.M., Wiebe J.J., Ruessler D.S. \& Kernaghan N. 2002. Effects of environmental pollutants on reproduction in situ: Endocrine active contaminants and effects on reproductive function in wildlife. Proc. Second International Symposium on Assisted Reproductive Technology (ART) for the Conservation and Genetic Management of Wildlife, Omaha, p.19-26.

Jobling S., Coey S., Whitmore J.G., Kime D.E., Van Look K.J., McAllister B.G., Beresford N., Henshaw A.C., Brighty G., Tyler C.R. \& Sumpter J.P. 2002. Wild intersex roach (Rutilus rutilus) have reduced fertility. Biol. Reprod. 67(2):515-524.

Kuiper H. \& Distl O. 2004. Intersexuality in dogs: Causes and genetics. Dtsch. Tierärztl. Wochenschr. 111(6):251-258.

Lamesch A.J. 1992. Unilateral anorchidism or monorchidism. Chirurgie 118:328-332.

Latch E.K., Amann R.P., Jacobson J.P. \& Rhodes Jr E. 2008. Competing hypotheses for the etiology of cryptorchidism in Sitka black-tailed deer: An evaluation of evolutionary alternatives. Animal Conservation 11(3):234-246.

Lyle S.K. 2007. Disorders of sexual development in the dog and cat. Theriogenology 58(3):338-343.

Mansfield K.G. \& Land E.D. 2002. Cryptorchidism in Florida panthers:
Prevalence, features, and influence of genetic restoration. J. Wildl. Dis. 38:693-698.

Mattos M.R.F., Simões-Mattos L. \& Domingues S.F.S. 2001. Cryptorchidism in Dog. Ciênc. Anim. 10:61-71.

Mendez J.P., Schiavon R., Diaz-Cueto L., Ruiz A.I., Canto P., Söderlund D., Diaz-Sanchez V. \& Ulloa-Aguirre A. 1998. A reliable endocrine test with human menopausal gonadotropins for diagnosis of true hermaphroditism in early infancy. J. Clin. Endocrinol. Metab. 83:35233526.

Michalski F., Cullen Jr L., De Oliveira T.G. \& Crawshaw P.G. 2001. Felid cryptorchidism in Atlantic forest fragments: Evidence of inbreeding in free-ranging populations? Mammalia 65(4):548-550.

Mulayim B., Demirbasoglu S. \& Oral O. 2003. Unicornuate uterus and unilateral ovarian agenesis associated with pelvic kidney. Surg. Endosc. 17:161.

Pierson M., Vidailhet M., Wuilbercq L., Wendremaire-Palandri Y. \& Combescure B. 1983. Total testicular regression syndrome or anorchidism. Arch. Fr. Pediatr. 40:767-773.

Reijnders P.J.H. 1986. Reproductive failure in common seals feeding on fish from polluted coastal waters. Nature 324:456-457.

Reis R.H. 1966. Unilateral urogenital agenesis with unilateral pregnancy and vascular anomalies in the cat (Felis domestica). Wasmann $\mathrm{J}$. Biol. 24:209-222.

Serban A.M., Ionescu B., Damian A., Stoica T., Iliescu I. \& Maximilian C. 1965. An unusual form of anorchidism. Stud. Cercet. Endocrinol. 16:581-588.

Sinch C. \& Madan M.L. 1997. Pituitary and ovarian response to PMSG and $\mathrm{GnRH}$ of a gonadal dysgenetic buffalo. Vet. Rec. 140:533.

Tomov T. \& Ankov V. 1987. Hypothalamo-hypophyseal-adrenal and hypothalamo-hypophyseal-gonadal interactions in young persons with different forms of male hypogonadism. Vutr. Boles. 26:81-88.

Tzvetkova P., Tzvetkov D., Kanchev L. \& Yanev V. 1997. HCG stimulation test for diagnosis of androgen deficiency. Arch. Androl. 39:163-171.

Val P. \& Swain A. 2005. Mechanisms of disease: Normal and abnormal gonadal development and sex determination in mammals. Nat. Clin. Pract. Urol. 2(12):616-627.

Wildt D., Pukazhenthi B., Brown J., Monfort S., Howard J. \& Roth T. 1995. Spermatology for understanding, managing and conserving rare species. Reprod. Fertil. Dev. 7:811-824.

Wiig O., Derocher A.E., Cronin M.M. \& Skaare J.U. 1998. Female pseudohermaphrodite polar bears at Svalbard. J. Wildl. Dis. 34(4):792796.

Yu M.L., Guo Y.L., Hsu C.C. \& Rogan W.J. 2000. Menstruation and reproduction in women with polychlorinated biphenyl (PCB) poisoning: Long-term follow-up interviews of the women from the Taiwan Yucheng cohort. Int. J. Epidemiol. 29:672-677. 